\title{
Systematic review of ototoxic pre-surgical antiseptic preparations - what is the evidence?
}

\author{
Shubhi Singh ${ }^{*}$ (D) and Brian Blakley
}

\begin{abstract}
Objective: There is uncertainty regarding the safety of surgical antiseptic preparations in the ear. A systematic review of the literature was conducted to assess the evidence regarding ototoxicity of surgical antiseptic preparations.
\end{abstract}

Methods: A literature search was conducted using the PRISMA methods. Key words included "ototoxicity" "hearing loss", "antiseptic", "surgical preparation", "tympanoplasty", "vestibular dysfunction", "chlorhexidine", "iodine", "povidone", "ethanol", and "hydrogen peroxide" using Medline, Embase, Cochrane Library, Scopus and Web of Science. We included peer-reviewed papers that 1) objectively measured ototoxicity in humans or animals through hearing, vestibular function or histologic examination, 2) studied topically applied surgical antiseptic preparations, 3) were either in English or had an English abstract. We excluded papers that were 1) in vitro studies, 2) ear trauma studies, 3) studies of ototoxic ear drops intended for therapy, or 4) case reports. Studies included in the final review were screened using the PRISMA method.

Current systematic review registration number pending: 83,675.

Results: Fifty-six papers were identified as using PRISMA criteria. After applying our exclusion criteria, 13 papers met overall study criteria. Of these, six papers reported ototoxicity of iodine based solutions, five papers reported ototoxicity of chlorhexidine and ethanol and two papers assessed hydrogen peroxide. All papers reviewed were animal studies. lodine based solutions show least harm overall, while chlorhexidine and high concentrations of alcohol based solutions showed most harm. The evidence on hydrogen based solutions was inconclusive.

Conclusions: The overall evidence for anyone antiseptic solution is weak. There is some evidence that iodine, chlorhexidine, hydrogen peroxide and alcohol based antiseptics have ototoxicity. Conclusive evidence for human ototoxicity from any solution is not strong.

Keywords: ototoxicity, hearing loss, antiseptic, vestibular dysfunction, chlorhexidine, iodine, povidone, ethanol, hydrogen peroxide

\section{Background}

Antiseptic cleaning of skin prior to surgical intervention is the standard of care globally. Pre-surgical antiseptic preparation has been known to reduce the number of wound infections when used adequately [1]. However some standard antiseptic preparations have been shown to cause toxicity to the eyes and ears when used in head

\footnotetext{
* Correspondence: shubhi.singh@dal.ca

Division of Otolaryngology-Head and Neck Surgery, University of Manitoba, Health Sciences Centre GB421, 820 Sherbrook Street University of Manitoba, Winnipeg, MB R3T 2N2, Canada
}

and neck surgery [2]. Currently, in otologic surgery, there remains uncertainty regarding the safety of surgical antiseptic preparations in the ear. This has been a long standing area of concern as described in a case series conducted by Bicknell et al. in the early 1960s. Bicknell et al. describe varying degrees of morbidity following tympanoplasty surgery, ranging from high frequency hearing loss to "dead ears" with the main commonality between patients being pre-surgical preparation of the ear with chlorhexidine [3]. The purpose of this study was to conduct a systematic review of the literature to 
assess the evidence regarding ototoxicity of standard surgical antiseptic preparations. The focus of this study was to review ototoxicity of povidone-iodine, chlorhexidine gluconate, ethanol and hydrogen peroxide.

\section{Methods}

A systematic literature review was conducted using various combinations of the following key words: "ototoxicity", "hearing loss", "antiseptic", "surgical preparation", "tympanoplasty", "vestibular dysfunction", "chlorhexidine", "iodine", "povidone", "ethanol", and "hydrogen peroxide" using the databases: Medline, Embase, Cochrane Library, Scopus and Web of Science through September 2016. Further studies were obtained through screening references from relevant articles and the authors' own databases and grey literature including legal proceedings. Criteria for inclusion of a published article in this review were applied to the collected studies by two independent reviewers.

Studies included were peer-reviewed papers that 1) objectively measured ototoxicity in humans or animals through hearing, vestibular function or histologic examination, 2) studied topically applied surgical antiseptic preparations, 3) were either in English or had an English abstract. Excluded studies were 1) in vitro studies, 2) ear trauma studies, 3) studies of ototoxic ear drops intended for therapy and 4) case reports. Studies included in the final review were screened using the PRISMA method [4].

Each paper identified through PRISMA criteria was reviewed for the following data items including: experimental subjects, solutions and concentrations tested and objective measure of ototoxicity. Objective measure of ototoxicity was defined as having any of the following: audiological or vestibular testing done before and after exposure to the solution, histological examinations or gross pathologic examinations. Due to the broad variation in objective measures of ototoxicity, no direct meta-analysis of the data was conducted between studies. However, the data obtained from the final results of studies meeting the set criteria in all studies are summarized in Tables 1,2 and 3. Sources of error for these studies are further assessed in the discussion section.

\section{Results}

Fifty-six studies were identified through database searches and searches of relevant article references. Using pre-set criteria as mentioned above, 43 articles were eliminated as outlined in Fig. 1. Of the final 13 articles included in this review; six pertained to iodine based solutions, five to chlorhexidine and ethanol and two papers to hydrogen peroxide. All papers identified were animal studies.
Of the papers assessing the ototoxicity of povidoneiodine, Aursnes et al. found that povidone-iodine solutions in $70 \%$ alcohol with greater then $10 \mathrm{~min}$ of middle ear exposure to the solution caused an increase in cochlear damage [5]. Ichibangase et al. assessed ototoxicity of povidone-iodine $10 \%$ solution in guinea pigs of varying ages [6]. They found that those animals deemed to be infant or young had increased cochlear toxicity compared to adult guinea pigs. One reason they suggested for this finding was increased permeability of the round window membrane in infant versus adult guinea pigs as the membrane thickens with age [6]. Of the studies pertaining to povidone-iodine scrubs that contain detergents, all studies found that scrubs caused higher ototoxicity than povidone-iodine solutions, suggesting that detergent facilitates entry of the scrub into the inner ear [6-8].

In studies assessing chlorhexidine gluconate solutions, Igarashi et al. found that a concentration of $0.05 \%$ caused no change in Auditory Brainstem Response (ABR) from baseline after three applications of solution to the middle ear [9]. Perez showed that after three applications of $0.5 \%$ chlorhexidine gluconate to the middle ear of sand rats, no ABR were present in previously normal hearing animals [10]. Finally, three applications of chlorhexidine solution at $2.0 \%$ concentration caused destruction of outer hair cells on histological examination of the cochlea. Concentrations of 0.05 and $2.0 \%$ were shown to cause thick serous middle ear discharge on gross pathological examination. Similarly,. Perez et al. found that 70\% Ethyl Alcohol caused gross pathological changes to the middle ear space including erythema and edema. In some animals oedema of the external ear canal was so severe that testing of hearing was not possible [10]. Morizono et al. tested several strengths of ethanol ranging from 0.1 to $100 \%$ pure ethanol in the middle ear cavities of chinchillas [11]. They concluded that there was evidence of ototoxicity for ethanol concentrations greater than $10 \%$ using cochlear microphonics [11].

Finally, Perez et al. and Nader et al. assessed the ototoxicity of $3 \%$ hydrogen peroxide solutions [12]. While Nader et al. found no difference in ABR from baseline after a 5 min exposure of $3 \%$ hydrogen peroxide to the middle ear of chinchillas, Perez et al. found the majority of sand rats tested had an increase in threshold from an average of $55 \mathrm{~dB}$ to $108 \mathrm{~dB}$ after 5 applications of $3 \%$ hydrogen peroxide $[12,13]$.

\section{Discussion}

In this review, we identified 13 studies showing the ototoxicity of povidone-iodine, chlorhexidine gluconate, ethanol/ ethyl alcohol and hydrogen peroxide in controlled non-trauma settings. All studies were 
Table 1 Results for iodine-based antiseptic preparations

\begin{tabular}{|c|c|c|c|c|}
\hline Author, Year & Population & Intervention & Control & Outcome \\
\hline J Aursnes, 1982 [5] & $\begin{array}{l}28 \text { Guinea Pigs. } \\
\text { Baseline Preyer's } \\
\text { reflex measured } \\
\text { in all study animals. }\end{array}$ & $\begin{array}{l}\text { Solutions tested: } \\
\text { a) lodine in } 70 \% \text { alcohol } \\
\text { b) lodophor in } 70 \% \text { alcohol } \\
\text { c) lodine in aqua dest. } \\
\text { d) lodophor in aqua dest. } \\
\text { Exposure time } 10,30 \text { or } 60 \text { minuets. } \\
\text { Histopathology assessed after } \\
2 \text { weeks }\end{array}$ & $\begin{array}{l}\text { Contralateral ear to } \\
\text { experimental ear }\end{array}$ & $\begin{array}{l}\text { a) Gross examination of the ear } \\
\text { showed no mucosal changes after } \\
10 \text { mins of exposure for lodine or } \\
\text { lodopher in aqua dest. } \\
\text { b) Middle ear mucosal damage } \\
\text { worst for solutions in } 70 \% \text { alcohol. } \\
\text { c) Cochlear damage with exposure } \\
\text { time of } 60 \text { min with lodophor in } \\
70 \% \text { alcohol. } \\
\text { d) Vestibular damage seen with } \\
\text { lodophor in } 70 \% \text { with } \\
\text { exposure times of 30-60min }\end{array}$ \\
\hline T Morizono, 1982 [7] & 30 Chinchilla & $\begin{array}{l}\text { Solutions tested: } \\
\text { a) Povidone-iodine Solution at 1:10 } \\
\text { dilution ( } 1.0 \% \text { available iodine) } \\
\text { b) Povidone-iodine Scrub* at } \\
\text { 1:10 dilution ( } 0.75 \% \text { available iodine) } \\
\text { c) Povidone-iodine Scrub at } \\
\text { 1:100 dilution } \\
\text { Exposure time } 10 \text { mins } \\
\text { Effect on Compound Action } \\
\text { potential (CAP) tested } 2 \text { hours, } \\
24 \text { hours post exposure } \\
\text { *Scrub contains detergent }\end{array}$ & $\begin{array}{l}\text { Contralateral ear } \\
\text { to experimental ear }\end{array}$ & $\begin{array}{l}\text { a) Povidone-iodine Scrub more } \\
\text { toxic to cochlear function } \\
\text { then solution } \\
\text { b) Evoked action potential } \\
\text { measure at round window, } \\
\text { no change } 2 \text { hours after } \\
\text { exposure with 1:10 dilution of } \\
\text { lodine Solution } \\
\text { c) Evoked action potential } \\
\text { measure at round window } \\
2 \text { hours after exposure with } \\
\text { 1:10 dilution of lodine } S c r u b \\
\text { caused severe depression at all } \\
\text { tested frequencies ( } 2,4,8,12 \mathrm{kHz} \text { ) } \\
\text { d) Increased toxicity with } \\
\text { increased concentrations } \\
\text { for both solution and scrub }\end{array}$ \\
\hline T Morizono, 1983 [8] & 30 Chinchilla & $\begin{array}{l}\text { Solutions at different dilutions } \\
\text { d) Povidone-iodine Solution at } \\
\text { 1:10 dilution (1.0\% available iodine) } \\
\text { e) Povidone-iodine Scrub* at } \\
\text { 1:10 dilution ( } 0.75 \% \text { available iodine) } \\
\text { f) Povidone-iodine Scrub at } \\
\text { 1:100 dilution } \\
\text { Duration of exposure time 10mins } \\
\text { Effect on Compound Action } \\
\text { potential (CAP) tested } 2 \text { hours, } \\
24 \text { hours post exposure } \\
\text { *Scrub contains detergent }\end{array}$ & $\begin{array}{l}\text { Contralateral ear } \\
\text { to experimental ear }\end{array}$ & $\begin{array}{l}\text { a) High frequency losses } \\
(8 \text { and } 12 \mathrm{kHz} \text { ) after } 10,30 \\
\text { and } 120 \mathrm{~min} \text { exposure to } \\
\text { iodine scrub at 1:100 dilution }\end{array}$ \\
\hline T. Inchibangase, 2011 [6] & $\begin{array}{l}70 \text { Guinea Pigs - Divided into } \\
\text { groups based on age } \\
\text { (infant, young and adult) }\end{array}$ & $\begin{array}{l}\text { Solution tested } \\
\text { a) Povidone-iodine } 10 \% \text { solution } \\
\text { b) Povidone-iodine scrub } \\
\text { Effect on Compound Action } \\
\text { potential (CAP) tested at } 24 \mathrm{~h} \text {, } \\
7 \text { days and 28days }\end{array}$ & $\begin{array}{l}\text { Contralateral ear } \\
\text { to experimental ear }\end{array}$ & $\begin{array}{l}\text { a) No action potential at } \\
24 \text { hours after application of } \\
\text { Povidoneiodine scrub } \\
\text { b) } 24 \text { hours after exposure to } \\
\text { povidone-iodine } \\
\text { solution, significant ototoxicity } \\
\text { measured in infant group, less in } \\
\text { young and least in adult } \\
\text { c) } 8 \text { fold dilution of povidoneiodine } \\
\text { solution showed no hearing loss in } \\
\text { adults, loss for young at } 2 \text { and } 4 \mathrm{kHz} \\
\text { d) Showed aged related variation } \\
\text { associated with ototoxicity in } \\
\text { guinea pigs }\end{array}$ \\
\hline M. Ozkiris [16] & 24 Sprague-Dawley Rats & $\begin{array}{l}\text { Solution tested } \\
\text { a) } 5,7.5,10 \% \text { Povidone-iodine } \\
\text { solutions } \\
\text { No exposure time given. } \\
\text { Otoacoustic emissions } \\
\text { measured at } 1 \text { and } \\
10 \text { days after exposure }\end{array}$ & $\begin{array}{l}\text { Contralateral ear } \\
\text { to experimental ear }\end{array}$ & $\begin{array}{l}\text { a) At } 5 \% \text { concentration some } \\
\text { statistically significant decreased } \\
\text { hearing at day } 1 \text { but resolved } \\
\text { by day } 10 \\
\text { b) At } 7.5 \% \text { and } 10 \% \text {, day } 10 \\
\text { results showed decreased in } \\
\text { hearing in frequencies ranging } \\
\text { from } 1.5-12 \mathrm{kHz}\end{array}$ \\
\hline R. Yagiz, 2003 [17] & 7 adult guinea pigs & $\begin{array}{l}\text { Solution Tested } \\
\text { a) Povidone-iodine } 10 \% \text { solution } \\
\text { No exposure time given. Hearing } \\
\text { tested at } 10 \text { days and } 4 \text { weeks } \\
\text { after exposure }\end{array}$ & $\begin{array}{l}\text { a) Saline as a negative control in } \\
\text { the contralateral ear to experimental } \\
\text { ear in } 4 \text { animals } \\
\text { b) Gentamycin as a positive control } \\
\text { the contralateral ear of } 3 \\
\text { experimental animals }\end{array}$ & $\begin{array}{l}\text { a) } 4 \text { animals could not be tested } \\
\text { due to severe oedema of } \\
\text { the external auditory canal } \\
\text { b) No Otoacustic emissions } \\
\text { present 10days or } 4 \\
\text { weeks after exposure }\end{array}$ \\
\hline
\end{tabular}


Table 2 Results for chlorhexidine and ethanol-based antiseptic preparations

\begin{tabular}{|c|c|c|c|c|}
\hline Author, Year & Population & Intervention & Control & Outcomes \\
\hline R. Perez, 2000 [10] & 25 Sand Rats & $\begin{array}{l}\text { a) Solutions tested } \\
\text { Povidone-iodine } 10 \% \\
\text { solution } \\
\text { b) Chlorhexidine } \\
\text { Gluconate } 0.5 \% \text { solution } \\
\text { c) Ethyl alcohol in } 70 \% \\
\text { aqueous solution } \\
\text { Exposure time } 3 \text { days } \\
\text { ABR and vestibular evoked } \\
\text { potentials (VsEP) testing } \\
8 \text { days after initial exposure }\end{array}$ & $\begin{array}{l}\text { a) Saline as } \\
\text { negative control } \\
\text { b) Gentamycin } \\
\text { as positive control }\end{array}$ & $\begin{array}{l}\text { a) ABR not present after } \\
\text { Chlorhexidine Gluconate } \\
0.5 \% \text { solution } \\
\text { b) ABR present at baseline } \\
\text { after application of } \\
\text { Povidone-iodine } 10 \% \\
\text { solution, VsEP present } \\
\text { in all test animals } \\
\text { c) No ABR or VsEP recorded } \\
\text { in } 2 / 5 \text { animals after Ethyl } \\
\text { alcohol } 70 \% \text { solution, } 3 / 5 \\
\text { had elevated } \\
\text { thresholds ( } 70-80 \text { dB) } \\
\text { d) Erythema and oedema } \\
\text { noted in } 5 / 5 \text { middle ear } \\
\text { cavities after application } \\
\text { of ethyl alcohol }\end{array}$ \\
\hline Y. Igarashi, 1985 [9] & 12 Cats & $\begin{array}{l}\text { Solutions tested } \\
\text { a) Chlorhexidine } \\
\text { Gluconate } 2.0 \% \\
\text { b) Chlorhexidine } \\
\text { Gluconate } 0.05 \% \\
\text { Exposure time every } \\
2 \text { days } \times 3 \text { applications. } \\
\text { Histologic examination } \\
\text { at } 7 \text { days and } 4 \text { weeks }\end{array}$ & $\begin{array}{l}\text { Contralateral ear to } \\
\text { the experimental ear }\end{array}$ & $\begin{array}{l}\text { a) Gross examination of } \\
\text { middle ear space showed } \\
\text { thick serous fluid } \\
\text { retention in } 12 / 12 \text { animals } \\
\text { b) Histological examination } \\
\text { showed loss of outer hair } \\
\text { less in lower cochlear turns, } \\
\text { with } 85 \% \text { loss near the } \\
\text { round window after } \\
\text { application of Chlorhexidine } \\
\text { gluconate } 2 \% \text { solutions } \\
\text { c) Little to no damage to } \\
\text { the outer hair cells seen with } \\
\text { Chlorhexidine } 0.05 \% \text { solution }\end{array}$ \\
\hline J. Aursnes, 1981 [14] & 48 Guinea Pigs & $\begin{array}{l}\text { Solutions tested } \\
\text { a) Chlorhexidine } \\
0.1 \% \text { in } 70 \% \text { alcohol } \\
\text { b) Chlorhexidine } \\
0.1 \% \text { in aqua. Solution } \\
\text { c) Chlorhexidine } \\
0.5 \% \text { in } 70 \% \text { alcohol } \\
\text { d) Chlorhexidine } \\
0.5 \% \text { in aqua. Solution } \\
\text { Exposure time } 10 \text {, } \\
30 \text { and } 60 \text { mins. } \\
\text { Histological examination } \\
\text { done after } 2,3,4 \\
\text { or } 10 \text { weeks post exposure }\end{array}$ & $\begin{array}{l}\text { Contralateral ear } \\
\text { to experimental ear }\end{array}$ & $\begin{array}{l}\text { a) Gross examination showed } \\
\text { extensive fibrotic tissue } \\
\text { after } 60 \text { min exposure time } \\
\text { b) Greater degree of fibrosis } \\
\text { with } 0.5 \% \text { solution compared } \\
\text { to } 0.1 \% \text { solution } \\
\text { c) Total destruction of outer } \\
\text { hair cells seen } 3 \text { weeks after } \\
\text { exposure with } \\
\text { Chlorhexidine } 0.5 \% \\
\text { in } 70 \% \text { alcohol }\end{array}$ \\
\hline H. G. Galle, 1986 [18] & 2 Guinea Pigs & $\begin{array}{l}\text { Solution tested } \\
\text { a) Savlon }{ }^{\mathrm{TM} *} \text { in } \\
\text { 1:100 dilution } \\
\text { Cochlear microphonics, } \\
\text { histologic examination } \\
\text { and behaviour measured } \\
\text { at } 24 \mathrm{~h} \text { and } 48 \mathrm{~h} \text { after exposure } \\
{ }^{*} \text { Composed of } 1.5 \% \\
\text { Chlorhexidine Gluconate } \\
\text { and } 0.15 \% \text { cetrimide } \\
\text { (quaternary } \\
\text { ammonium compound) }\end{array}$ & $\begin{array}{l}\text { Contralateral ear } \\
\text { to experimental ear }\end{array}$ & $\begin{array}{l}\text { a) Severe vestibular } \\
\text { dysfunction based } \\
\text { on behaviour but effects } \\
\text { diminished after } 24 \mathrm{~h} \\
\text { and again after } 48 \mathrm{~h} \\
\text { b) Hearing thresholds } \\
\text { increased from baseline } \\
\text { of } 35 \mathrm{~dB} \text { to } 70 \mathrm{~dB} \mathrm{SPL}\end{array}$ \\
\hline T. Morizono, 1981 [11] & 23 Chinchillas & $\begin{array}{l}\text { Solutions tested } \\
\text { a) Ethanol in contractions } \\
\text { of } 0.1,1,3,10,25,50,70 \text { and } 100 \% \\
\text { Exposure time was } \\
\text { 10mins, } 24 \text { h. Cochlear } \\
\text { mircophonics and } \\
\text { endocochlear } \\
\text { Action potentials tested }\end{array}$ & $\begin{array}{l}\text { Contralateral ear } \\
\text { to experimental ear }\end{array}$ & $\begin{array}{l}\text { a) Variable outcomes } \\
\text { with some animals showing } \\
\text { decrease in all frequencies } \\
\text { tested with cochlear } \\
\text { microphonics with } 3 \% \\
\text { solutions while others } \\
\text { showed no } \\
\text { deficits with } 50 \% \text { solution }\end{array}$ \\
\hline
\end{tabular}

animal studies and no direct human correlation can be drawn given the differences in anatomy of the middle ear space, dosing of antiseptic preparations and in some cases the duration of exposure being in the order of several weeks. However, some solutions showed high ototoxicity in relatively low concentrations and short exposure times. This includes povidone-iodine scrub which contains detergent, 
Table 3 Results for hydrogen peroxide-based antiseptic preparations

\begin{tabular}{|c|c|c|c|c|}
\hline $\begin{array}{l}\text { Author, } \\
\text { Year }\end{array}$ & Population & Intervention & Control & Outcome \\
\hline $\begin{array}{l}\text { R. } \\
\text { Perez, } \\
2003 \\
{[13]}\end{array}$ & $\begin{array}{l}22 \text { Sand } \\
\text { Rats }\end{array}$ & $\begin{array}{l}\text { a) Hydrogen } \\
\text { peroxide } 3 \% \\
\text { solution } \\
\text { Exposure } \\
\text { time } 5 \text { days. } \\
\text { ABR and VsEP } \\
\text { tested on day } \\
8 \text { after initial } \\
\text { exposure }\end{array}$ & $\begin{array}{l}\text { a) Saline as } \\
\text { negative } \\
\text { control } \\
\text { b) } \\
\text { Gentamicin } \\
\text { as positive } \\
\text { control }\end{array}$ & $\begin{array}{l}\text { a) ABR could not } \\
\text { be tested in } 3 / 12 \\
\text { animals. All } \\
\text { remaining animals } \\
\text { had elevated base } \\
\text { line from } 55 \mathrm{~dB} \text { to } \\
108 \mathrm{~dB} \\
\text { b) VsEP could not } \\
\text { be recorded in 5/ } \\
12 \text { animals. All } \\
\text { remaining animals } \\
\text { had a increased } \\
\text { from baseline of } \\
\text { mean latency time }\end{array}$ \\
\hline $\begin{array}{l}\text { ME } \\
\text { Nader, } \\
2007 \\
{[12]}\end{array}$ & $\begin{array}{l}18 \\
\text { Chinchillas }\end{array}$ & $\begin{array}{l}\text { Solution } \\
\text { tested } \\
\text { a) Hydrogen } \\
\text { peroxide } 3 \% \\
\text { solution } \\
\text { Exposure } \\
\text { time } 5 \text { min } \\
\text { ABR } \\
\text { performed } \\
1 \text { day after } \\
\text { exposure }\end{array}$ & $\begin{array}{l}\text { Contralateral } \\
\text { ear to } \\
\text { experimental } \\
\text { ear }\end{array}$ & $\begin{array}{l}\text { b) No difference of } \\
\text { ABR from baseline } \\
\text { recording prior to } \\
\text { instillation of } \\
\text { hydrogen } \\
\text { peroxide. }\end{array}$ \\
\hline
\end{tabular}

povidone-iodine in $70 \%$ alcohol, and chlorhexidine gluconate in $70 \%$ alcohol [5-7, 14]. However for other solutions there is no consensus from the studies identified. (Tables 1, 2 and 3).

There are several limitations of this current review. The methods and objective measures are inconsistent.

All the studies identified in this review were animal studies so we are cautious about drawing conclusions from different species using different methods on the potential of the solutions to cause damage in human subjects. In studies conducted on guinea pigs and chinchillas the main hypothesized method of inner ear penetration for solutions is through the round window. The Chinchilla round window membrane is $1 / 6$ of the thickness of that of humans therefore this model is likely over estimating ototoxicity in humans [15].

There are also several challenges differentiating conductive hearing loss from sensorineural hearing loss in animal subjects. The time period over which animals were assessed may not have been adequate [7].

\section{Conclusion}

Given the findings of this review, the evidence of human ototoxicity of currently used antiseptic preparations is not strong. Iodine based, non-alcoholic, non-detergent solutions may be the least ototoxic but all should be used with caution.

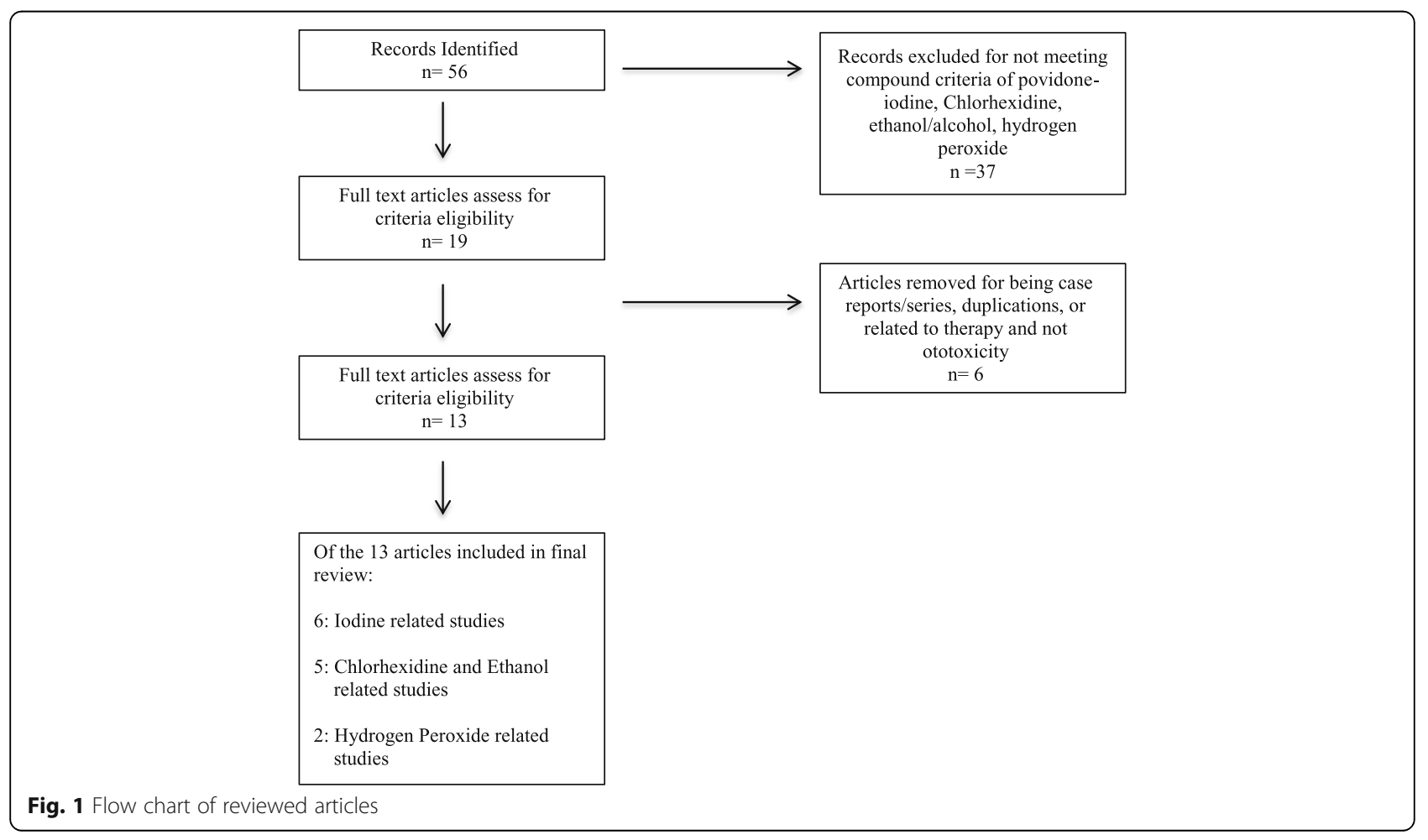




\section{Abbreviations}

ABR: Auditory Brainstem Response; CAP: Compound Action Potential; PRISMA: Preferred Reporting Items for Systematic Reviews and Meta-Analysis; SPL: Sound Pressure Level; VsEP: Vestibular Evoked Potential

\section{Funding}

No funding was obtained for preparation of this manuscript.

\section{Availability of data and materials}

No datasets were generated during this review. All papers included in the final review are presented in the body of the paper in Tables 1, 2 and 3.

\section{Authors' contributions}

Both authors of this paper were responsible for screening articles obtained through databases researches for inclusion in the final paper. Dr. SS was responsible for setting database search criteria and database searches, review inclusion criteria and preparation of the final manuscript. All authors read and approved the final manuscript.

\section{Ethics approval and consent to participate}

No ethics approval was sought as this was a systematic review of previously published papers. All papers reviewed in preparation of this manuscript are included in Tables 1, 2 and 3. The database containing all papers generated by the review criteria is available upon request.

\section{Consent for publication}

Not applicable.

\section{Competing interests}

The authors declare that they have no competing interests.

\section{Publisher's Note}

Springer Nature remains neutral with regard to jurisdictional claims in published maps and institutional affiliations.

\section{Received: 10 June 2017 Accepted: 6 February 2018}

\section{Published online: 01 March 2018}

\section{References}

1. Mangram AJ, Horan TC, Pearson ML, Silver LC, Jarvis WR, Committee HICPA. Guideline for prevention of surgical site infection, 1999. Am J Infect Control. 1999;27:97-134.

2. Steinsapir KD, Woodward JA. Chlorhexidine Keratitis: Safety of Chlorhexidine as a Facial Antiseptic. Dermatologic Surgery 2016.

3. Bicknell P. Sensorineural deafness following myringoplasty operations. J Laryngol Otol. 1971;85:957-62.

4. Liberati A, Altman DG, Tetzlaff J, et al. The PRISMA statement for reporting systematic reviews and meta-analyses of studies that evaluate health care interventions: explanation and elaboration. PLoS Med. 2009;6:e1000100.

5. Aursnes J. Ototoxic effect of iodine disinfectants. Acta Otolaryngol. 1982;93:219-26

6. Ichibangase T, Yamano T, Miyagi M, Nakagawa T, Morizono T. Ototoxicity of Povidone-lodine applied to the middle ear cavity of guinea pigs. Int J Pediatr Otorhinolaryngol. 2011;75:1078-81.

7. Morizono T, Sikora MA. The ototoxicity of topically applied povidone-iodine preparations. Arch Otolaryngol. 1982;108:210-3.

8. Morizono T, Sikora MA. Compound action potential input-output decruitment: effect of topically applied antiseptics. Arch Otolaryngol. 1983 109:677-81.

9. Igarashi Y, Suzuki J-I. Cochlear ototoxicity of chlorhexidine gluconate in cats. Arch Otorhinolaryngol. 1985;242:167-76.

10. Perez R, Freeman S, Sohmer H, Sichel JY. Vestibular and cochlear ototoxicity of topical antiseptics assessed by evoked potentials. Laryngoscope. 2000; 110:1522-7.

11. Morizono T, Sikora MA. Ototoxicity of ethanol in the tympanic cleft in animals. Acta Otolaryngol. 1981;92:33-40.

12. Nader ME, Kourelis M, Daniel SJ. Hydrogen peroxide ototoxicity in unblocking ventilation tubes: a chinchilla pilot study. Otolaryngol Head Neck Surg. 2007;136:216-20.
13. Perez R, Freeman S, Cohen D, Sichel JY, Sohmer H. The effect of hydrogen peroxide applied to the middle ear on inner ear function. Laryngoscope. 2003;113:2042-6.

14. Aursnes J. Cochlear damage from chlorhexidine in guinea pigs. Acta Otolaryngol. 1981;92:259-71.

15. Rauch S. Membrane problems of the inner ear and their significance. J Laryngol Otol 1966; 80:1144-155.

16. Özkiriş M, Kapusuz Z, Saydam L.Ototoxicity of different concentrations povidone-iodine solution applied to the middle ear cavity of rats. Indian Journal of Otolaryngology and Head \& Neck Surgery. 2013;65:168-72.

17. Yagiz R, Tas A, Uzun C, Adali MK, Koten M, Karasalihoglu AR. Effect of topically applied povidone-iodine on transient evoked otoacoustic emissions in guinea pigs. J Laryngol Otol. 2003;117:700-3.

18. Galle $H$, Haagen AW. Ototoxicity of the antiseptic combination. Vet Q 1986; $8.56-60$.

\section{Submit your next manuscript to BioMed Central and we will help you at every step:}

- We accept pre-submission inquiries

- Our selector tool helps you to find the most relevant journal

- We provide round the clock customer support

- Convenient online submission

- Thorough peer review

- Inclusion in PubMed and all major indexing services

- Maximum visibility for your research

Submit your manuscript at www.biomedcentral.com/submit 